\title{
RECENT ADDITIONS TO THE SCULPTURES OF THE PARTHENON.
}

\section{[Plate V.]}

THE principal object of the present paper is the publication of a remarkable addition to the west pediment of the Parthenon, which is due to the practised eye of Herr Karl Schwerzek of Vienna. At the same time I would take the opportunity of calling attention to other additions and corrections which have been made in the last two or three years, in the sculptures of the Parthenon, as represented by the collection in the Elgin Room of the British Museum. Most of them have already been pointed out in the Catalogue of Sculpture in the Department of Greek and Roman Antiquities, British Museum, Vol. i. (1892), but a somewhat fuller discussion seems desirable than is consistent with the scheme of a Catalogue.

\section{The West Pediment of the Parthenon.}

The figure, which is known according to the system of notation introduced by Prof. Michaelis as $Q$, with her attendant figures $P, R$, was still in good preservation in 1674, when the pediment was drawn by Jacques Carrey for the Marquis de Nointel. Carrey's drawing of the three figures and of the adjoining group is reproduced in the annexed cut (Fig. 1), which has been taken from the facsimile in the British Museum, corrected in certain details from the photograph published in the Antike Denkmaeler, Vol. i. Pl. 6. Á female figure, apparently complete except for her left forearm, sits to the front on an irregular rocky seat, with her right arm lying in her lap. At each side was a small figure of a boy. It was recognized by Visconti, and has never been questioned, that a portion of the group was extant in the collection of Lord Elgin. The fragment in question ${ }^{1}$ consists of the lap and lower limbs of the female figure. The feet, drawn by Carrey, are wanting. The drapery was a long chiton, and a mantle, of which a part falls over the knees, where it lies in deep folds as if slightly agitated and puffed out by a breeze. Together with this fragment of the female figure, a part of the boy at her right side has always been extant, since his thighs,

1 No. 304 P, Q; Mus. Marbles VI. Pl. 19 ; Michaelis, Parthenon Pl. 8, Fig. 19. See Pl. V, in this volume. 
pubis, right hand, and drapery are still preserved in one piece with the principal figure $Q$.

We owe to Herr Schwerzek the identification of the upper half of the figure of the boy, who is now almost restored to the condition in which he stood when seen by Carrey.

Among the fragments in the Elgin collection are two male torsos, not dissimilar in size, which have always been accepted without question as belonging to the metopes. They are so described in the Synopsis of 1817 and elsewhere. They are engraved as a vignette on the title-page of Part VII. of the Museum Marbles, and are said to have 'evidently been broken from some of the metopes' (p. 3). One of the two torsos ${ }^{2}$ is undoubtedly a part of one of the metopes of the south side (Michaelis, Pl. 3

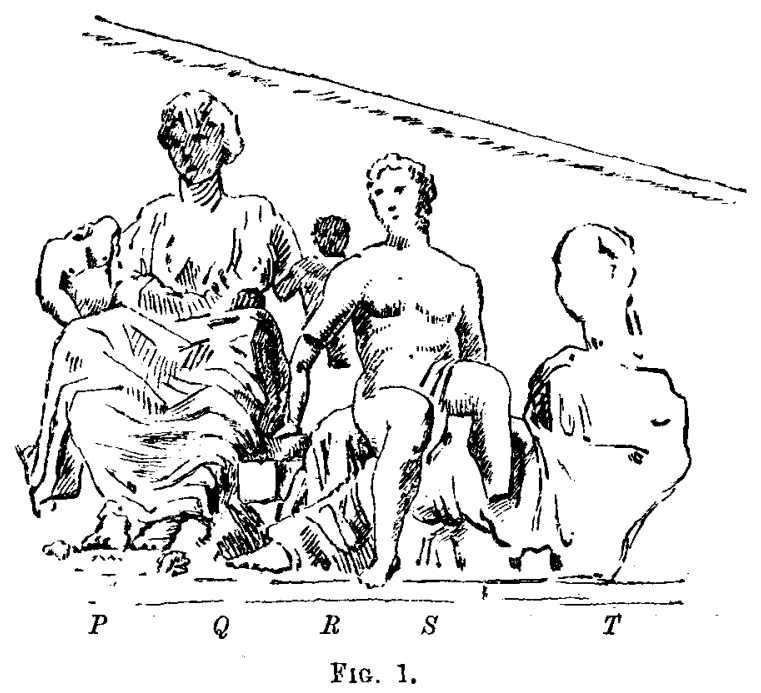

No. xvi.) which was seen complete by Carrey, and which was destroyed in the great explosion. This attribution, which was established from the pose of the torso, was made more certain, a few years ago, when it was found that the Lapith head presented by the late Duke of Devonshire in 1859 could be attached to the torso. The companion fragment was assigned by Michaelis to the metope No. xiv. of the south side, which like No. xvi. was drawn by Carrey, and afterwards destroyed in the explosion. Michaelis observes (text, p. 133) that in this metope 'only the torso of the youth is certainly preserved, for that it belongs to this place can hardly be doubted.' The group to which the torso was thus assigned consists, in Carrey's drawing, of a woman holding a flat dish or basket in the left hand, and some uncertain object in the right hand, and of a youth nude except for a large mantle, who appears to be raising his left hand in horror or astonishment. 
The torso, as drawn by Michaelis, fits fairly though not perfectly with Carrey's drawing, and his attribution has been accepted without hesitation. ${ }^{3}$

In November, 1892, Herr Schwerzek made an examination of the torso when siudying the Parthenon fragments with a view to a restoration of the west pediment on which he is engaged. With a sculptor's eye he observed that the forms are soft and full like those of a young boy, and are not of the dry muscular character of the Lapiths of the metopes. Further, the figure was worked completely in the round, which was a cause for suspicion, though not in itself conclusive, as the figures of the metopes are in parts wholly disengaged from the background. For these reasons he suggested a trial, and with a plaster squeeze of the fractured surfaces it was easily ascertained that there was an unmistakable fit over an area of about four square inches, although the first sharpness of the surfaces had been somewhat worn away.

The torso is now fixed in position, as shown in Plate $\mathrm{V}$ from two points of view, and has given significance to the parts of the figure which were previously known.

The boy stands close to the woman, and turns towards her. The left arm was raised, and may have been placed on the woman's right shoulder. Her right arm is, I think, drawn by Carrey as lying across her waist, although this has been overlooked in many of the current copies of Carrey's drawing. From its position it must have been hard to see, but the sketch is confirmed by the fact that there is no trace of the arm round the boy's body which would have been a natural alternative position. The boy's right arm, which was complete in Carrey's time, is now missing from the middle of the upper arm, but its direction is certain. We see it start downwards from the shoulder and the fingers still rest on the woman's right knee. There they rest on an end of drapery, probably a small himation belonging to the boy, which can be seen passing round the left thigh. The boy's right leg, which is lost from below the knee, was evidently bent at the knee, as beyond that point there is no trace of it against the woman's drapery. He stood on a rocky step, described below, to which the figure was fitted.

The head and left arm have evidently been lost for a long time, and so far as the upper part of the figure is concerned, we now have it in the same condition as that in which it was seen by Carrey, except for the loss of the right arm. Here, as in other cases, additional knowledge only serves to increase our admiration for the wonderful accuracy of Carrey's hasty outlines. On the other hand it is worthy of notice that the sketch by 'De Nointel's Anonymous Artist,' ${ }^{4}$ which in truth appears to be nothing more than an unintelligent copy of Carrey, is absurdly wrong. The boy is represented as a mutilated trunk, seated in the woman's lap.

By the time of Dalton's visit to Athens in 1749 the torso of the boy seems to have disappeared from its place, as it is not indicated in Dalton's

${ }^{3}$ Guide to the Elgin Room, Part I. (cd. 1880) p. 39 ; Cat. of Sculpture, I. no. $342,2$.
4 Michaelis, Pl. 7 ; Antike Denkmueler, i. Pl. 7. 
sketch. ${ }^{5}$ This however is not conclusive evidence, since it would be nearly hidden from the point of view chosen by Dalton.

The question at once presents itself whether this addition to the group has any bearing on the interpretation of it, but $I$ fear that we are not brought any nearer to certainty. According to most of the older interpreters the group consists of Latona with Apollo and Diana, but it does not seem likely that two of the gods would be represented as children on the pediment. The view more favoured by later writers is that we have here Leucothea with Palaemon, while the child to the right is regarded as belonging to the next group. The lower part of the figure $Q$ is cut away square, so as to stand on and against a step. This step appears in Carrey's drawing to project to the right beyond the figure, and to furnish a footing for the right leg of the child $R$. But his left leg seems to have been supported on the knee of the reclining figure $T$ (Thalassa?) and he is thus brought into immediate connection with the nude figure $S$, often called Aphrodite.

An entirely new interpretation of the group has recently been proposed by Prof. Furtwaengler, in a paper read before the Archaeological Society of Berlin. As the paper is still unpublished, except for a brief summary of the results, ${ }^{7}$ it would be premature to discuss its conclusions in detail. According to the general scheme of interpretation we have the family of Cecrops $(B)$ on the left of the central group, and the family of Erechtheus on the right. The figure of Erechtheus himself does not now exist, and is not recorded to have existed by Carrey, but he is conjecturally interpolated between $U$ and $V$. Thus on the pediment, as in Attic mythology, the family of Cecrops is more specially identified with Athene, and the family of Erechtheus with Poseidon. We are at present only concerned with the figures immediately on the right of the central group which consists of the contending gods and their charioteers. Next to the charioteer of Poseidon, according to Furtwaengler, we have Oreithyia $(Q)$ with her Boread sons Zetes $(P)$ and Calais $(R)$, who are followed by Creusa $(T)$ with her son Ion $(S)$ in her lap.

Such is the scheme of Prof. Furtwaengler, and the idea of grouping the families of Cecrops and Erechtheus on the two sides of the pediment is attractive and ingenious. It is difficult however to see how the author will be able to establish his case with any degree of certainty, and several assumptions of doubtful validity are involved.

The whole scheme depends on the conjectural insertion of a figure of Erechtheus $\left(O_{1}\right)$ between $U$ and $V$. Opinion has been divided as to whether anything is missing in this place, and Sauer's newly-made plan $^{8}$ of the

5 Dalton's Engravings; Michaelis, Hilfstafel.

61 believe that Herr Schwerzek has suggested that Carrey's drawing may indicate a large shell below the feet of $Q$. If so, her marine character is established.

7 Arch. Anzeiger, 1891, p. 70. Here is the list of proposed identifications: $A$ Bouzyges, $A_{1}$ Wife of Bouzyges, $B$ Cecrors, $C-F$ Children of Cecrops, $G$ not stated, $H$ Hermes, $L$ Athene, $M$ Poseidon, $N$ Iris (=J of east pediment), $O$ Nereid, $\boldsymbol{P}$ Zetes, $Q$ Oreithyia, $R$ Calais, $S$ Ion, $T$ Creusa, $U$ Daughter of Erechtheus who was sacrificed, $U_{1}$ Erechtheus, $V$ Boutes, $W$ Wife of Bontes.

${ }_{8}$ Athenische Mittheilangcn, 1891, Pl. 3 p. 67. 
floor of the pediment seems to leave no room whatever for the missing figure.

The nude figure $S$, here called Ion, is interpreted as male. This has been done already, especially by Loeschcke ${ }^{9}$ who called the figure Heracles in the lap of Melite, and who is followed by Miss Harrison, ${ }^{10}$ so far as the sex is concerned.

To make the figure male avoids the difficulty presented by a nude female figure in a pediment of the Parthenon, but the fact is hardly open to question that both Carrey and Dalton independently saw the figure as female and so drew it. It seems unsafe to set our views of what is or is not possible against the testimony of two independent and competent witnesses.

The discovery of our fragment proves that the child $P$ was wingless, as appears also in Carrey's drawing. But the sons of Boreas as we know them on the vases and elsewhere are stalwart figures, always winged and often bearded. They have wings in Pindar, Pyth. iv. 181 and in scenes where they pursue the Harpies, as on the chest of Kypselos and the throne of the Amyclaean Apollo.

Hence, even if we grant that Pheidias chose to represent them as children with their mother, we should expect them to be winged in order to conform as far as possible to the ordinary type. For the idea that the sons of Boreas were born without wings, and that their wings only grew with their beards, no better authority is quoted than Ovid (Met. vi. 712).

\section{The Central Group of the West Pediment.}

The terra-cotta lamp, of which a cut is here given (Fig. 2), was acquired: from Cyprus by the British Museum in 1884, but has not hitherto been published. The work is roughly moulded and slight, but the group has the interest which attaches to every fresh representation of the strife between Athene and Poseidon, as suggesting possible interpretations of the action of the central group of the west pediment.

The diameter of the relief is $1 \frac{3}{4}$ inches. Athene steps quickly forward from the left, with her shield raised on her left arm. Her right hand is also advanced, but its action is not clearly defined. She wears a long chiton, an upper chiton girt at the waist, a small mantle flying from her shoulders, and a crested helmet. There are no traces of an aegis. Poseidon, on the right, appears to be slightly drawing back. The right hand is raised and extended as if deprecating the advance of Athene. He is half draped by a mantle which passes round the legs and over the left arm, and in his left hand he holds the trident. The olive-tree occupies the middle of the field. The token of Poseidon is not represented. There does not appear to be a serpent coiled round the stem of the tree, although the roughness of

9 Dorpat Programm, 1884.

10 Myths and Monuments of Ancient Athens, p. 445. Sauer (loc. cit. pp. 79, 80) has attri- buted two male fragments to this figure, which would be conclusive, if the correctness of the attribution could be established. 
the work prevents certainty on the point, and there is no owl in the branches.

The moment represented on the lamp appears to be that of the accomplished decision. Athene steps forward with her shield-arm raised, not so much as assaulting Poseidon (for in that case Poseidon would necessarily assume a more hostile attitude), but rather as standing forth, almost in the position of a Promachos, to guard her sacred token, and at the same time the city that she has won, against all the world. Poseidon meanwhile draws back with right arm raised. It may be suggested that this is also a not impossible interpretation ${ }^{11}$ of the action of the central group of the pediment, whether we admit or reject any connection between it and the lamp. The most obvious difference is that the Athene of the lamp is turned in the opposite direction to that of the pediment. The discrepancy however is less, if we

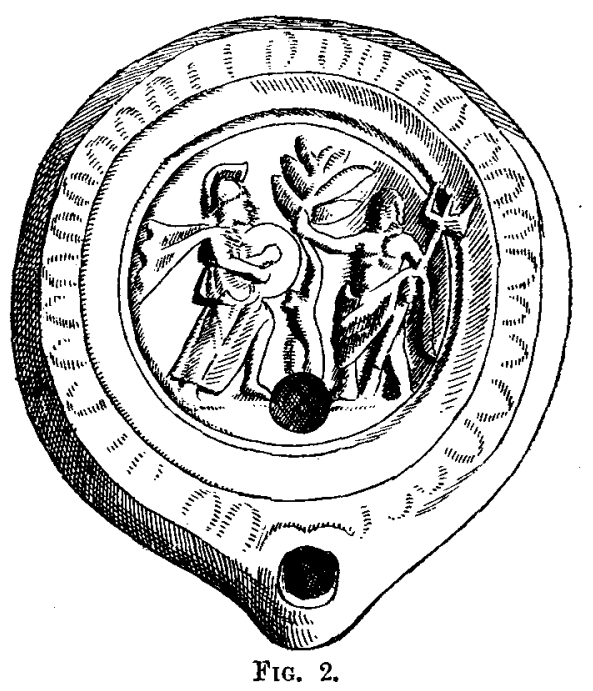

suppose that the Athene of the pediment was stepping somewhat forwards as well as outwards. In Carrey's drawing Athene and Poseidon are both full face to the spectator and in the same plane with one another. Such a position seems unnatural, and makes it hard to find room in which to dispose the various figures. If, which seems more probable, the two figures were somewhat turned round, so as to partly face one another, the group would be less remote from that of the lamp. In that case the whole figure of Athene would be best represented by the marble statuette from Epidaurus, quoted in this connection by Miss Harrison.

Just as in the Myronian group of Athene and Marsyas, Athene throws down the flutes and strides away, hardly deigning to look back at the Satyr, who makes a gesture of surprise and alarm, so on the pediment she looks back only at Poseidon, while she steps forth as the champion of her olive.

"This suggestion is partly due to Herr Schwerzek. 


\section{The Metopes.}

The head of a Lapith, ${ }^{12}$ of which an illustration is published here (Fig. 3) for the first time, was discovered in the last Acropolis excavations, I believe in the year 1889. The fragment consists of the left side of a head, with the beginning of the neck. It is split away, along the natural grain of the marble, through the angle of the right eye and the right angle of the mouth. The nose and upper lip have also been broken off. The fragment is a part of an ideal youthful. head of the rather meagre type of the Parthenon metopes, from which it is undoubtedly derived. The proportions agree, the hair and eyes are similarly treated, and the general effect is alike. A closer

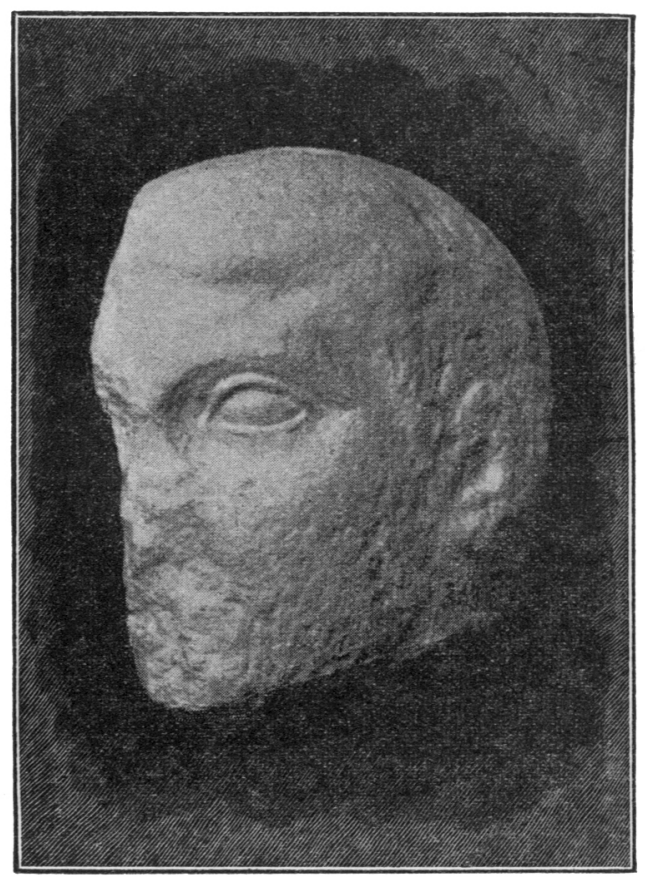

F[G. 3 .

examination shows that the head was turned to the right, when it was still in position. The left ear is only roughly sketched out, and the surface round it has only been partially finished. In particular a mass of material has been left standing immediately behind the ear, and there still remain conspicuous tool-marks. Moreover the whole of this side of the head is

12 Catalogne of Sculpture in Brit. Mus. I. no. 342, 6. Height from crown of head to below chin $6 \frac{3}{4}$ in. 
somewhat flattened. The corrosion, so far as it is possible to judge from what remains to us, was more extensive on the right side of the head than on the left.13 Everything therefore indicates that this fragment is the inner side of a head turned to the spectator's right, imperfectly worked because difficult of access, on account of its nearness to the ground of the relief.

So far, attempts to fit the fragment to a torso have been unsuccessful. Assuming that our choice is limited to the metopes of the sonth side, the possible alternatives would seem to be Michaelis, Pl. 3. Nos. ii, viii, ix, xiv, xxiii, xxiv, xxvi, xxvii.

If further we assume that the head was dislodged in comparatively recent times, the choice is further restricted to ii, viii, ix, xiv, xxiv, xxvii, the remaining heads having been lost before the time of Carrey. Of these viii is excluded by the angle at which the chin joins the neck. I do not think it is possible to limit the choice any further. This however is less to be legretted than would otherwise be the case since, if the head were placed in position, it would chiefly exhibit to the spectator the side on which the marble has been split away.

\section{The Frieze.}

Several fragments of the frieze were found in the Acropolis excavations of 1888-9. One fragment-the head of Iris-which had been broken off at a very early period, belongs to the east side. The remaining fragments, so far as I am aware, had been broken off at a more recent period, and belong to the east half of the north side of the frieze. They had probably been dislodged in the explosion, and lay on the ground until they found safety in burial among the fragments which the Turkish governors hardly dared to sell to travellers though they readily burnt them into lime. ${ }^{14}$

\section{The East Side.}

The head of Iris in the east frieze has already been published with the fulness that its beauty deserves, ${ }^{15}$ and $I$ therefore only need mention it briefly. This head is, on account of its admirable preservation, a valuable

13 Compare Dr. Waldstein's analysis of another Lapith head in an earlier volume of this Jmernal (J.H.S. iii. p. 231).

14 A curious passage in the letters of Lady Craven, who was afterwards Margravine of Anspach, describes how she would gladly have picked up the broken pieces of the Parthenon sculpture that lay on the ground, but conld not have 'even a little finger or a toe.' She had come, in May 1786, in a vessel sent by ChoiseulGouffier to remove senlpture, but the governor representer that if anything were taken, his enemies would have the excuse that they wanted for having his head struck off. Meanwhile the marbles were being freely burnt into lime. A Journey to Corstantinople by Elizabeth Lady Craven, Dnblin, 1789, p. 333.

${ }^{15}$. By Dr. Waldstein, who assisted at the discovery and identification, in the American Jourin. of Archacology, v. P1. 2. p. 1. The present appearance of the slab is given in the Cat. of Sculpture in the Brit. Mus. I. P1. 6, Fig. 1 . 
addition to the frieze. It was found in the lower courses of a piece of masonry on the Acropolis, said to be of the Byzantine period; its loss may therefore well have been one of the first mutilations that the Parthenon suffered. It may, as suggested by Dr. Waldstein, have been broken off from its slab, when the slab was removed in the course of alterations for the purposes of the church, and have been immured soon after in the place in which it was found. Meanwhile the main slab, changing its position from time to time, but always within reach of the ground, was seriously injured. ${ }^{16}$ All the heads on the slab are defaced, and exhibit tool-marks showing that the mutilation was deliberate. The Iris alone was in safety. The earliest drawing of the slab, that of Stuart, shows the head to be wanting, ${ }^{17}$ as was necessarily the case if the masonry in which the head was found is correctly dated. In the fragment we have the head of Iris turned outwards to the left, while she raises the coil of her hair with her left hand.

\section{The Norti Side.}

The annexed illustration (Fig. 4) shows an additional fragment of slab ix, which contained a part of the group of old men. In the cut the extant

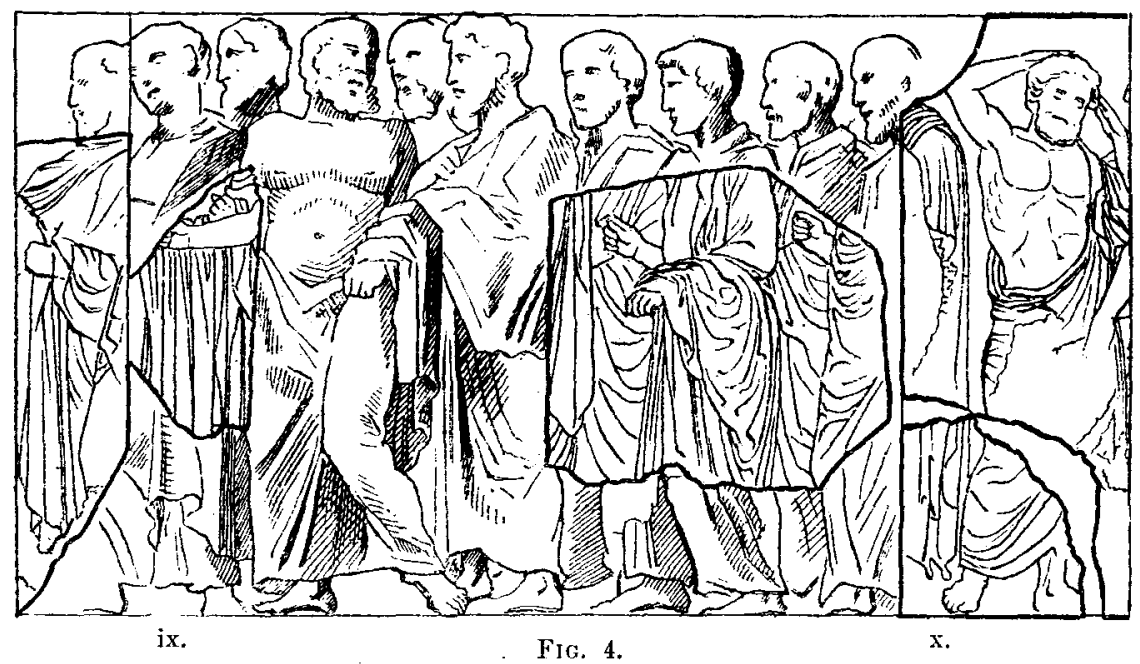

fragments are combined with Carrey's drawing in the manner introduced by Michaelis. This fragment, which was found in the recent Acropolis excavations, has a joint on its left side. This fixes its position in the slab and it is further identified by the conspicuous right forearm, held out horizontally, which belongs to the old man (Michaelis, No. 31) and which is duly

\footnotetext{
16 For the history of the slab, so far as it is known, see Michaelis, p. 258.

${ }^{17}$ Dr. Waldstein is mistaken (loc. cit. pp. 6,

8) in speaking of a restoration of Iris by Stuart, and in the Muscum Worslcyanum. The fracture is correctly indicated in both cases.
} 
given by Carrey. It is not surprising that Carrey should have failed to notice the clenched left hand of No. 30 which is seen just issuing from the folds of his himation. At the left of the slab is a part of the drapery of the figure No. 29. The lower corner of slab $x$ is a less recent addition, but it is not given by Michaelis.

Figure 5 shows the present condition of the first of the chariot groups on the north side of the frieze. The newly added fragment, which contains the upper half of the Apobates, restores a fine figure to the frieze and at the same time furnishes a good means of judging the comparative values of Carrey and Stuart as authorities for missing portions.

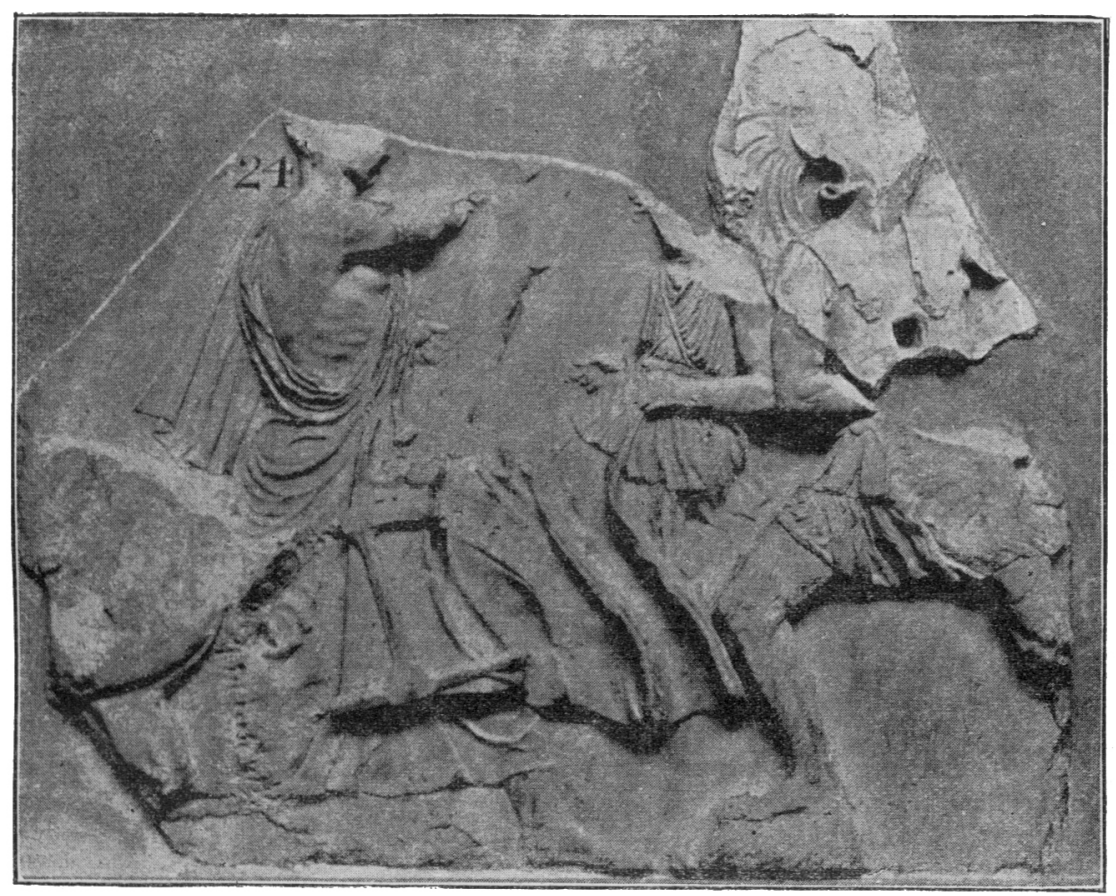

FIG. 5.

We have here the figure of an Apobates fully armed with a crested helmet, cuirass with pendant flaps (pteryges) and circular shield. He turns back towards the following chariots, and raises his shield on his left arm as if to check their motion. The cuirass has some of the elaborate decoration which is found on one other figure of the frieze, the horseman, No, 11, on the west side. The shoulder straps in both cases terminate in lions' heads in low relief. The square hole in the middle of the breast, which is faithfully drawn by Carrer (Fig. 6), is peculiar. The bronze ornaments attached to the 
frieze were fastened by small round holes drilled in the marble. The large square hole sugests a marble dowel. Perhaps a Gorgoneion in marble may have been attached in the middle of the breast, as in the case of the rider on the west side, referred to above.
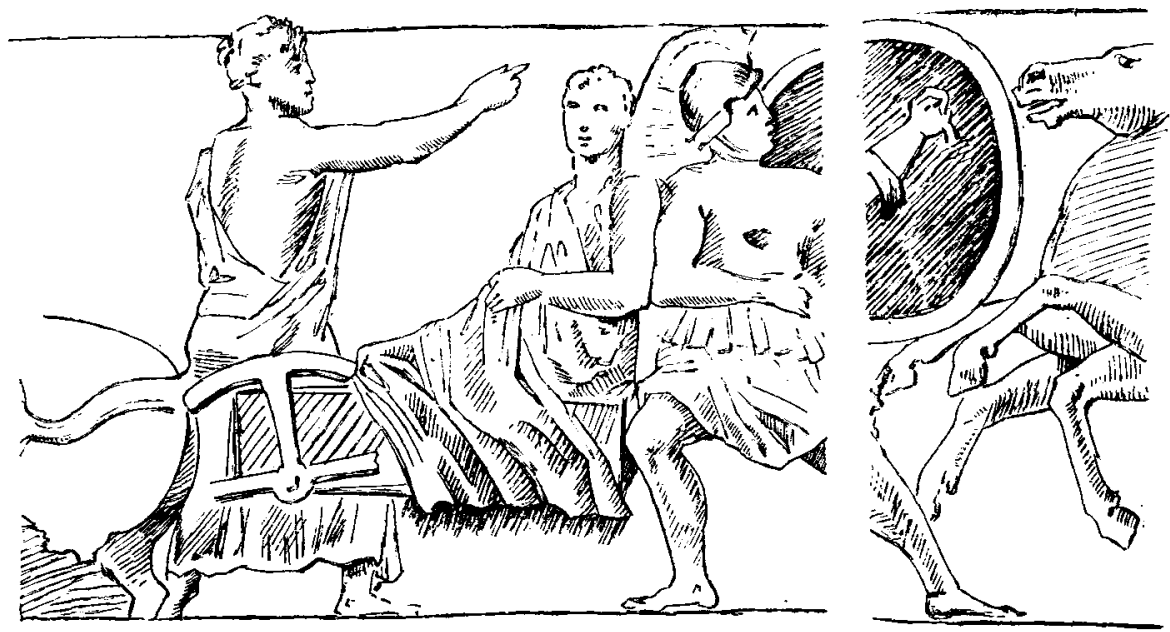

FIG. 6.

On the left edge of the new fragment, which was broken off before the time of Stuart, is a part of the hair of the charioteer. This is of some importance, because it proves that Stuart's drawing (Fig. 7), which makes the charioteer's head feminine, is not accurate. Part of the hair being on this fragment, and part being on the slab, only a narrow splinter of marble containing the face is missing. It is probable that this was broken off at the same time as the fragment with the Apobates, and that the line of fracture at the same time passed through the head of the marshal. In any case it is clear that Stuart's drawing is incorrect as representing the head as complete, and at some distance.from the edge of the marble. The chariot-wheel is also restored in Stuart's engraving, though reduced to its present state in the time of Carrey.

We have here a good example of the accuracy of Carrey, and of the untrustworthiness of the illustrations in Stuart's book. As regards the further question which presents itself, whether Stuart or his engravers were in fault, the almost total disappearance of Stuart's original materials makes it difficult to form an opinion. Something however may be gathered from the fragmentary papers that survive in the British Museum (Add. MSS. 22152,22153 ), of which I hope to give more account on another occasion. These papers give the impression that Stuart was a careful draughtsman, accurate in detail, and catching also the spirit of the originals, and that he suffered much at the hands of the engravers during his period of infirmity 
and after his death. For example a few of the measured drawings ${ }^{18}$ for the frieze of the monument of Lysicrates survive. These are sketched in a bold hand which has none of the un-Attic character of the engravings, and are afterwards covered with numerous measurements, in one instance more than fifty, which are chiefly in the form of vertical and horizontal co-ordinates.

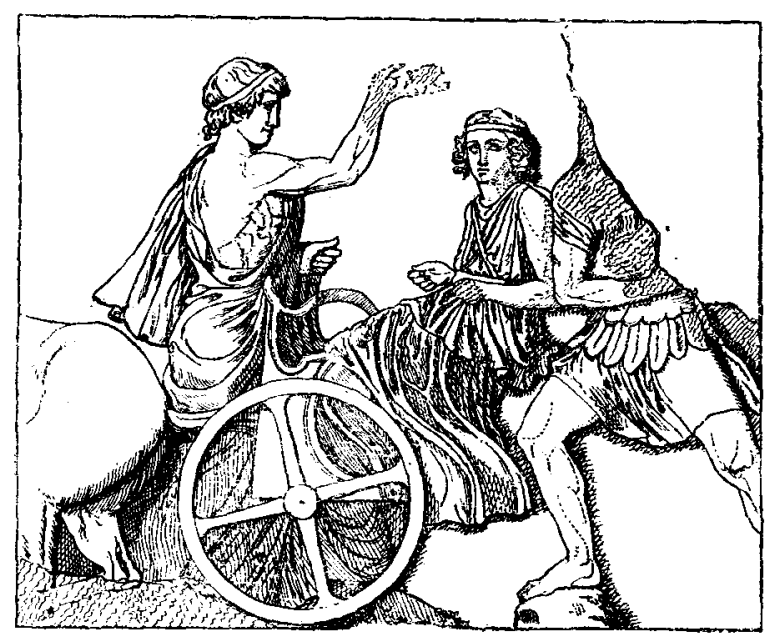

Fig. 7 .

So also on folio 76 we have the original sketch of the long missing Athenian relief with Athene and Marsyas, ${ }^{19}$ which is so strangely transformed in the engraving. As drawn by Stuart, the Athene and Marsyas are Greek in character, and the drawing is accurate, so far as can be judged from the remains of the relief. The engraver has added the Gorgoneion and altogether unclassical plume. $\mathrm{He}$ has interpolated the flutes, omitted the tail of Marsyas, caricatured both the faces, and weakened the pose of both figures. The ludicrous restoration ${ }^{20}$ of the female figure with the torch on the east frieze of the Parthenon, impossible for one who had seen the original figure, is clearly the work of the engraver, who misunderstood a rough sketch. In the present case therefore it is probably only fair to Stuart to credit his engraver with the restoration of the two heads and the chariot-wheel. The examples quoted above are enough to show that if Stuart's papers, many of which were found to be missing at the time of his death, ${ }^{21}$ could be traced, they might furnish much valuable matter. ${ }^{22}$

18 Cf. Antiqs. of Athens, I. Preface.

19 Antiqs. of Athens, I. p. 27 ; Arch. Zeit. 1874, Pl. 8. Miss Harrison, Myths and Monuments, p. 409 (relief reversed).

${ }^{20}$ Antiqs. of Athens, II. Chap. I. Pl. 25.

21 Antiqs. of Athens, Preface Vol. II.
22 Perhaps some reader is in a position to pursue the following clue to some of the lost Stuart papers. On Aug. 13, 1809, Mr. Nathaniel Barnardiston of Sudbury wrote to Josiah Newton of High Holborn, the publisher of vol. iv, of the Antiquitics of Athens: "The two

H 2 
The figure of the man leading the first cow in the next cut (Fig. 8) has recently been improved by the identification of the fragment containing a part of the elbow and drapery. This fragment is not one of the recent finds, but it had previously been misinterpreted as part of the drapery of a leg.

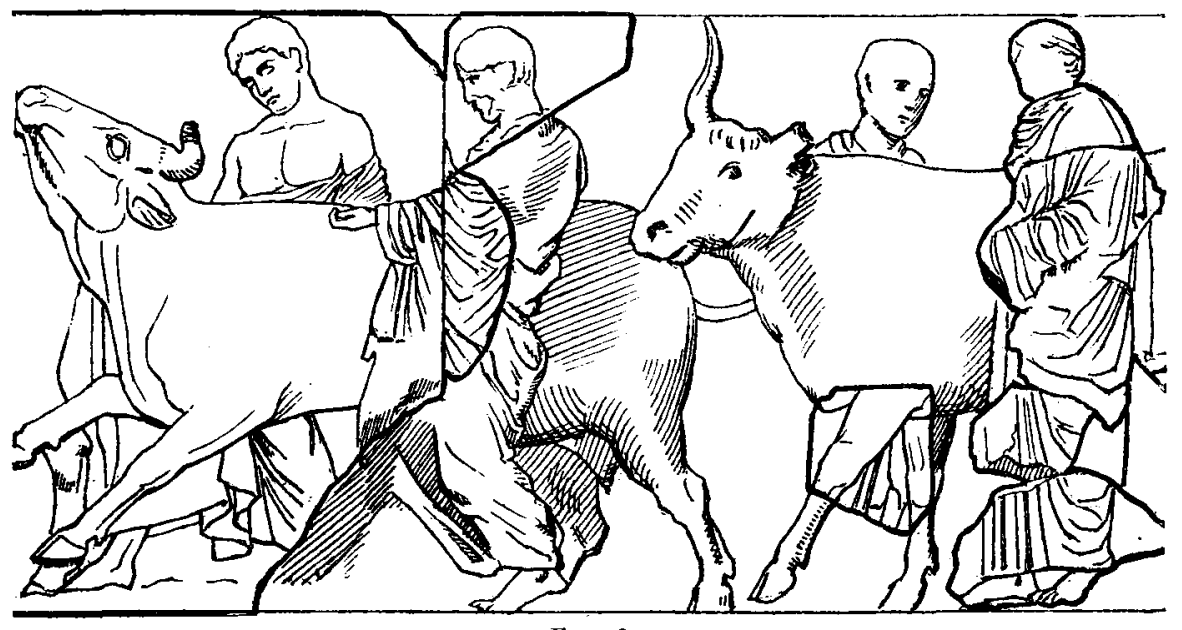

Fig. 8.

The head of the same figure and the greater part of the next figure but one are less recent additions, but they are all later than the publication of the work of Michaelis.

\section{A. H. SмITh.}

papers you mention in the Gentleman's Magazino for 1788 , vol. 58 signed A. H. respecting Stuart were very probably written by the late Anthony Highmore of Canterbury Esqre. (who was intimate with Stuart) and his son Mr. Highmore of Ely Place, Holborn, as a Friend to Literature, will communicate any information that he can obtain from his father's papers. If you should not be acquainted with him, be so good as give my compts. to him, and inform him the last time I had the pleasure of seeing his worthy Father, for whom I had the highest respect, I remember he showed me a vol. of Stuart's view's, given him by the author who was his particular friend etc.' Brit. Mus. $A d d$. MSS. 22152, fo. 31. Anthony Highmore of Canterbury was an artist (1719-1799), and father of Anthony Highmore a writer on law (1758-1829). Cnly one of the two papers is signed A. H. 


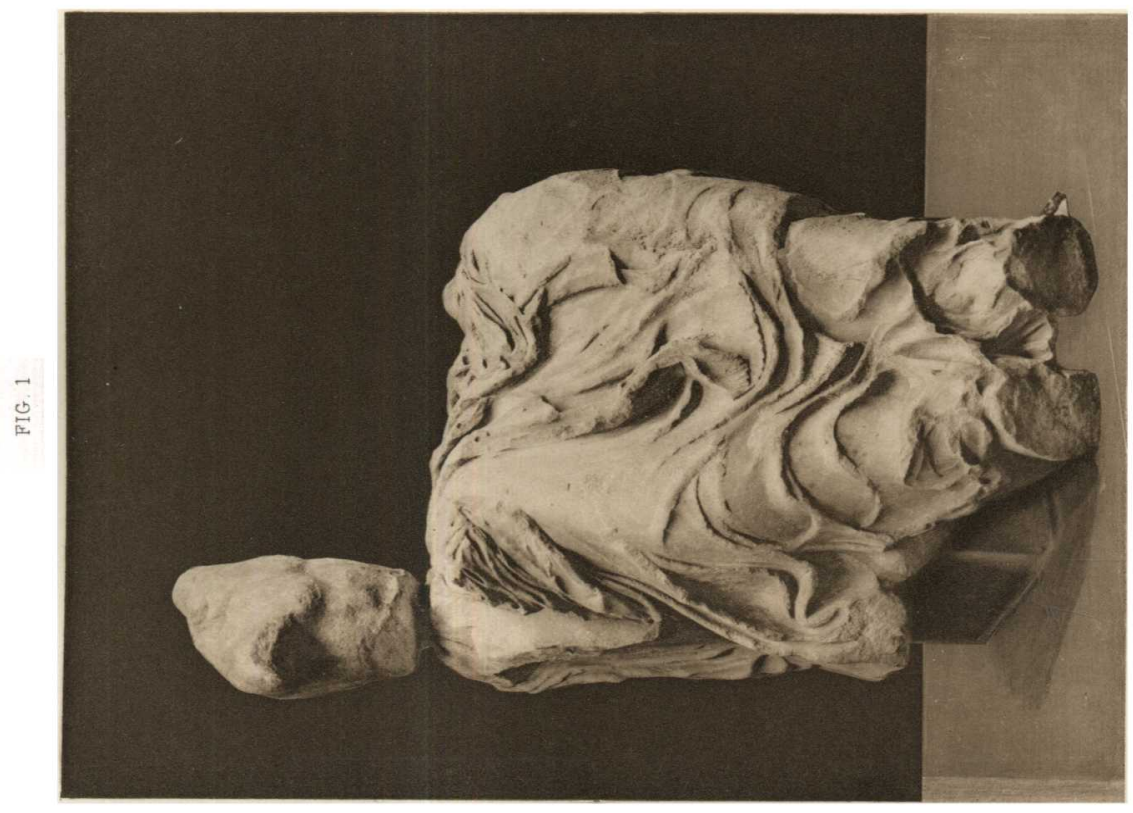

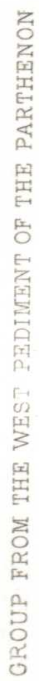

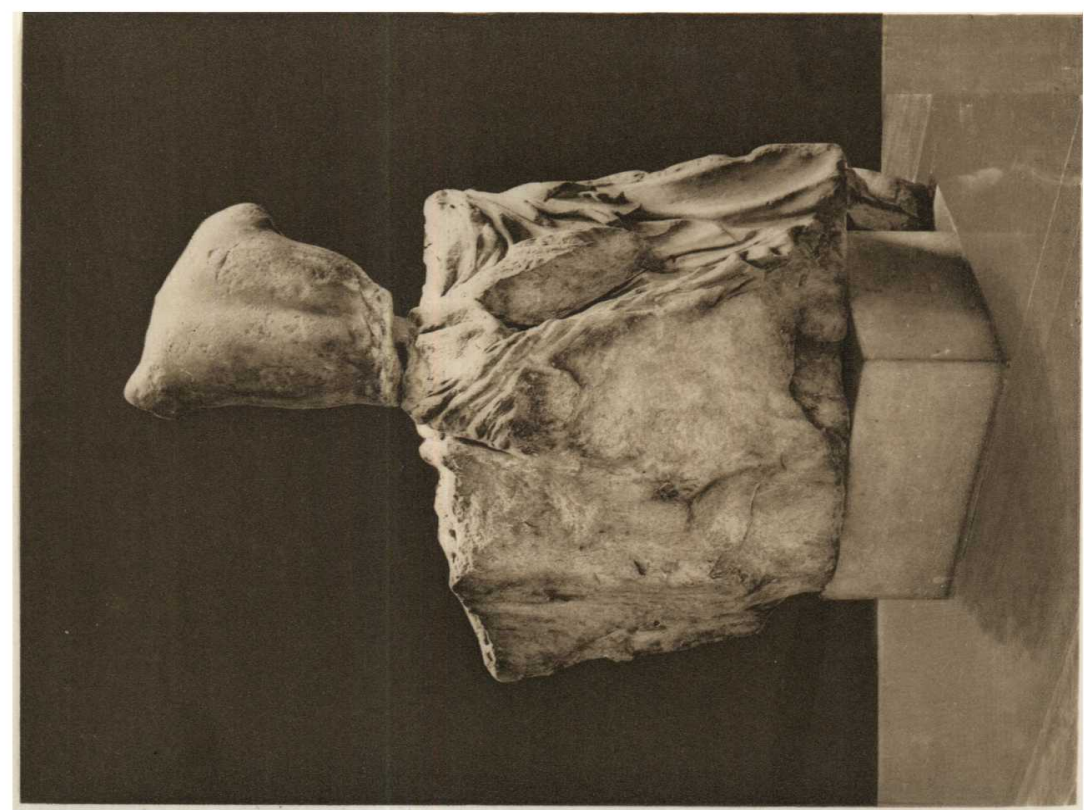

